\title{
COMMUNICATION PATTERNS AMONG KIAISOF NAHDLATUL ULAMA IN THE MADURESE ETHNIC GROUP
}

\author{
Akhmad Haryono \\ Faculty of Culture Science, University of Jember, Indonesia \\ aharyono.sastra@unej.ac.id; haryonos1967@gmail.com
}

First received: 17 October 2017

Final proof received: 31 January 2018

\begin{abstract}
Research on communication patterns with an ethnographic approach has been conducted by many linguists, but apparently there has hardly been any research on communication patterns within an NU society with its strong paternalistic cultural background. In fact, the uniqueness of this culture also has had a major influence on NU members' communication patterns in their daily interaction. This study aims to describe the communication patterns among kiais (venerated teachers of Islam) of Nahdlatul Ulama in the Madurese ethnic group (NUMME) and account for the factors affecting those patterns of communication. A qualitative method with an ethnographic approach was applied to achieve this research's objectives. The data were collected through participatory and non-participatory observations, interviews, note-taking, and recording. The recorded data were transcribed and analyzed descriptively using the components of speech analysis, conversational analysis, discourse analysis with pragmatic concepts, and explanation. This study found that giving an honor to the teacher in the NU tradition is an obligation and a tradition that is still maintained. This phenomenon is reflected in the patterns of communication among kiais that have teacher-student ties (KT-KS). The patterns of communication among kiais bearing teacher-students ties (KT-KS) are influenced by situational factors, i.e. formal and informal situations. In an informal situation the KT-KS patterns of communication are influenced by age differences. The age differences that affect the gaps of KT-KS patterns of communication both in formal and informal situations only find expression in the use of speech levels, while in terms of patterns of language selection, tones of voice, body language, and turn-taking, the differences were not found.
\end{abstract}

Keywords: communication patterns; Madurese ethnic group; ethnography

Communication patterns in this study are interactional models of the language use practicing particular speech codes, that are influenced by specific and recursive relationships among components of speech (Kuswarno, 2008). The term "communication patterns" in this research is defined as the category and the function of language which are reflected in the speech, the use of speech level, language choice and language variation as the realization of code switching and code-mixing, intonation (tone), and symbols performed through body movement (body language) as the supporting aspects in terms of understanding speech acts that occur in a verbal language, as well as turn-taking (Haryono, 2014).

The communication patterns between kiai as a teacher (KT) and kiai as a student (KS) discussed in this study refer to the analysis of the eight components of speech proposed by Hymes (1964); Schiffrin (1994) and Saville-Troike (2003) with the acronym SPEAKING elaborated as: (1) S: Situation/Setting 'place and the milieu of speech; (2) P: Participant 'speaker, object, hearer/ interlocutor';
(3) E: Ends 'result, purpose of speech'; (4) A: Act Sequence 'turn-taking'; (5) K: key: 'tone'; (6) I: instrumentalities 'speech instruments'; (7) N: norms 'interaction and interpretation norms'; (8) G: genres ' type of speech'. Haryono (2013; 2014) added another variable, Story, abbreviated as S, namely stories about admired people as a part of communication patterns and strategies. Hence, this variable can be added to the components of speech becoming the SPEAKINGS grid.

The components of speech are an analytical tool functioning as an identifier in the ethnographical study of communication. Therefore, by analyzing the characteristics of speech components that affect a communication event, it would be revealed that the patterns of communication of a speech community are merely a result of the reflection of relationship and function among the components of speech. According to Kuswarno (2008), the components of communication (speech components) can be well understood through an explanation of the general characteristics of language behavior. This idea says 
that the speech components can affect language behavior. Similarly, by observing the language behavior of a certain community, the aspects of speech components that can affect patterns of communication can also be elicited. In the data analysis, interaction norms related to the NU tradition and culture in the Madurese ethnic group will be put forward.

Nahdlatul Ulama (NU) is an organization firstly established by a group of pesantren scholars in the NU tradition. It identically consists of an assemblage of kiais (Muzadi, 2003). The NU society has a paternalistic culture, namely an Islamic school's (pesantren) culture requiring the students' (santri) obedience to a kiai (venerated teacher of Islam) as the teacher as it is performed continously and recursively either in college or even among society (Haryono, 2011).

Kiai himself has varied social statuses and influence in the NU community. With these varied positions and social statuses on the basis of their roles and positions in society, kiai in general has an almost similar behavior, namely ikram (glorifying each other). In the community of NU, the thing that distinguishes the status of one kiai from another is affected by a number of factors, yet the main factor which has become the most accepted norm is the kiai's role and position as that of a teacher-student. The role and position can be gained through himself or/and his predecessors. One kiai or elder kiai who has once served (ngabdi) to another kiai and his grandchildren who have ever been his students must give an honor ( $t a^{\prime} d z i m$ ) to kiai and his grandchildren who have become their teacher. There is also the title of teacher and student gained directly in the community due to one kiai's high knowledge followed by his practice in the middle of society, thus other kiais frequently ask and learn from him. For this reason, the kiai is also honored (ta'dzim) as a teacher. In this case, Haryono (2011) argues that NUMME's obedience to the kiai considered to be the teacher in all aspects of life constitutes a part of paternalistic culture which has been trusted in NUMME since they studied in an Islamic school.

The uniqueness of the tradition and the culture affect the patterns of communication that occur among kiais. The patterning occurs at any level of communication: citizens, groups, and individuals (Hymes, 1961). Saville-Troike (2003) further explained that its patterns are based on the role and certain groups in a society such as sex, social status, occupation, education level, rural and urban residences, geographic area, characteristic of group and also other social groups. The cultural uniqueness of the Madurese Ethnic group and NU members in Jember is a reason for scholars to be interested in conducting research and writing about those people with different views and foci of study. This current study certainly differs from the previous ones in three aspects.
First, an ethnographic study on communication by Sariono (2007) emphasizes more intensively on linguistic choice, code switching and code mixing of the Using society in Singotarunan village in Banyuwangi. In addition, Budhiono (2010) focuses on speech and meaning in force in the speech community of the Kaso people. These two studies analysed communication patterns involving the use of speech level, tone, body language, and turn-taking of speech which constitute the combination of cultural behaviour of Madurese ethnic members and NU Islamic school culture. Code switching and code mixing, according to Sariono (2007), aims and functions to indicate that the speaker and hearer belong to the same speech community members, namely the Using tribe, whereas in this research these two codes were used for formal relationships between a teacher and his students.

Second, an ethnographic study on communication by Wibisono (2005) only focuses on Madurese ethnicity (ME) in general, and does not analyzes ME with NU members. In addition, the ethnographic study by Wibisono and Haryono (2009) only analyzes ME community language of newly weds, whereas this research emphasizes more on the communication patterns of Nahdhatul Ulama Members of Madurese Ethnicity (NUMME) in Jember;

Third, the communication patterns analyzed by Haryono (2006) and the communication system analyzed by Wahyuningsih (2014) only focus on Islamic school culture, whereas the study of communication patterns by Setyowati (2013) focuses on communication science with the object of Javanese ethnicity.

This research, in particular, describes the uniqueness of communication patterns among kiais who possess teacher-student ties confined by formal and informal situations. These unique communication patterns occur because the role and position as a teacher and a student is not situated formally but merely as a convention that has become part of the tradition and culture of the NU society and Madurese ethnicity, so then, the patterns of communication are regulated by such a convention that the society holds on to strongly.

Based on the above explanation, the problem is formulated as "What are the patterns of communication among kiais that have a teacherstudent relationship both in formal and informal situations?"

\footnotetext{
Speech acts

According to Searle (1985), in language-mediated communication, speech acts are always present. He argues that language-mediated communication is not merely about symbols, words, or sentences, but it also refers to the product or the result of symbols, words, or sentences in the form of speech acts. Such
} 
language-mediated communication can be tangible statements, questions, and commands (Wijana, 2010; Yule, 1996). Concerning these three forms of speech acts, Wijana (2010) then provides the following examples:

(1) The weather is so cold.

(2) Are the trees we have been cultivating going to be chopped down?

(3) Go away!

Those three sentences, analysed from each structural point of view, belong to (1) declarative sentence, (2) interrogative sentence, and (3) imperative sentence. However, from a functional point of view, all of the aforementioned sentences represent functions that may be similar or different, depending on the speech contexts pertinent to who is speaking, to whom one is speaking, where one is speaking, and what purpose a conversation is intended to. For instance, the first speech context may not be a declarative sentence, but rather an indirect imperative, instructing someone to close the door or turn off the air conditioner. Likewise, speech number 2 may not be a pure question, as it may be an indirect strategy to influence an interlocutor to support the speaker's suggestion not to cut down the trees. While the utterance number 3 may also be a prohibition expressed literally, so the other person will not go.

Thus, a sentence, which formally has a relatively fixed form, may have different functions. As such, it is possible that an interlocutor can capture something which is expressed directly or indirectly, literally or not literally, and various other purposes because speakers and interlocutors have the same assumptions and interpretations of the speech rules along with the principles driving the course of reasonable speech, including various kinds of irregularities. In reasonable speech, a speaker usually wants to express something and expects that the interlocutor can capture or understand what he or she expresses in a rational way.

Implicature, presuppotion, inference, and reference

Implicature is an utterance, which implies something different from what is actually said. This difference denotes the speaker's intention, which is not explicitly expressed (Grice, 1975). Implicature is soundly related to the convention of meaningfulness, which occurs in communication. This concept, according to Mulyana (2005) is the difference between what is said and what is implied.

Conversational implicature is pragmatically determined by bearing factors beyond language, as put forward by Hymes (stated in Brown \& Yule, 1983) it comprises of speakers, listeners, the topic of conversation, time, place, connector, dialect, event, and message sent across. Due to the abundance of these driving factors, in conversation there emerge implicatures, accompanied by some utterances difficult to perceive by interlocutors.

In Pragmatics, presupposition is a presumption which is extracted from the context within which a sentence or statement is expressed. In this regard, context can be a situation, a conversation, a location, and so on. In addition, Nababan (1987) contends that all utterances have presuppositions in the form of reference or basic reference. It is this reference, which makes an utterance perceivable to interlocutors. Leech (2003) states that presupposition or presumption is open to not only one interpretation, but also many, depending on the context of when and where something takes place.

According to Ibrahim (1993), presupposition or presumption denotes the relationship between something said and something different emerging there from. For more details, Levinson (cited in Ibrahim, 1993) presents several examples concerned with such presupposition as the following.

(a) 'Harold felt sorry for he hurt Sandra, presupposed as Harold hurt Sandra

(b) Sally quit smoking, presupposed as Sally smoked

Based on the abovementioned elaboration and examples, presupposition is an assumption which may be either wrong or right.

Inference lexically means conclusion. As pointed out by Moeliono (cited in Mulyana. 2005), it refers to a process which a reader has to carry out in order to understand literal meaning, which is not present in a discourse established by a speaker or a writer. Therefore, in the study of spoken discourse, it is imperative that the listeners be able to infer the meaning of the speaker's expression.

In making inference, it is imperative that implicature, implied meaning resulting from what is said (explicature), be taken into account. This is like when a son- in-law is in a room being treated for his illness, and he hesitates to ask his parent-in-law to turn on the air conditioner. As a corollary, he says, "Why is it hot in here?" The implicature or implied meaning in this context is that he asks his parent-inlaw to turn it on, the meaning of which the parentin-law infers by turning it on.

In the same vein, Mulyana (2005) argues that a dialogic spoken discourse involves literal meaning, which cannot be simply determined by mere linguistic aspects, but also by situational context. As stated by Gumperz (1968) and Lubis (1993) a conversational inference is an interpretation process bound to a situation and context. Simply put, equipped with the interpretation, the listener in a conversation presupposes the speaker's want and generates pertinent responses. As such, it is obvious that a conversational inference is scaffolded by a situation and a context. 
Reference is the relationship between a word and a corresponding realia (Brown \& Yule, 1983). Lubis (1993) points out that a reference is considered to be a speaker's behaviour, which is then expressed by a writer. In other words, the reference of a sentence is actually determined by the speaker or listener. The listener or reader can only guess what is meant (being referred) although this many not be fully correct.

A reference, according to Halliday and Hasan (1992), consists of two traits, namely a situation reference (exophora) and a textual reference (endophora). Brown and Yule (1983) further summarizes that when interpretation of a word lies beyond the text, which means a situation and a context, the relationship is considered to be exophora. However, when the interpretation lies in a text, then it is embedded relation or endophora relationship presents beyond the text, while endophora refers to something present in the text. By contrast, a cataphora is what is being referred or what is previously mentioned. The difference between reference and reduction is the omission of certain parts of a sentence, intended to signify the ignorance to form and meaning in other sentences.

\section{Cooperative principle and politeness principle in communication}

The Cooperative principles in a conversation constitute a guide that needs to be observed and obeyed by speech participants involved in a particular speech event, in order to maintain smooth and effective communication and avoid misunderstanding. Grice (1975), Yule (1996), and Nadar (2008) point out that the cooperative principles possess a number of meanings, including adjusting the contribution of one's conversation in a desired way by complying with development of conversation context or situation and with the intent or direction agreed upon in the conversation one is involved in. It is necessary to adhere to the cooperative principles to gain more ease at explaining the relationship between meaning and power-such explanation fairly suffices, especially to solve the problems that arise in a trust-based approach.

Grice gives further details of the cooperative principles into the following four maxims or guidelines.

1. Maxim of quality: it deals with making a fine contribution to a conversation. Especially, it is advisable not to say something you consider wrong or something that is not corroborated by adequate evidence.

2. Maxim of quantity: it pertains to making your conversation contribution as informative as necessary within the conversation context-never contribute to a conversation more than required.
3. Maxim of relevance: it deals with making your conversation relevant.

4. Maxim of manner: this maxim necessitates speaking clearly, particularly by 1) avoiding ambiguity, 2) avoiding coercion; 4) speaking briefly, and 5) speaking regularly.

To be concerned with the cooperative principles, Leech, (1993) and Nadar (2009) put forward that some society in certain situations put more priority on one politeness principle over the others. This is the case among civilized societies, wherein politeness principles hold focal importance and cannot be considered to be supplementary to the cooperative principles. He then points out the following examples:

A: We'll all miss Bill and Agatha, won't we? B: Well, we'll all miss Bill

In the above conversation, B clearly violates the maxim of quantity, which is evident when A wants B to affirm A's opinion, B only affirms a part of his opinion and ignores the rest. Referring to the example, it can be inferred that the speaker argues that not everyone misses Agatha. Also, it is obvious that B intentionally suppressing this opinion, violating the maxim of quantity or maxim of clarity/completeness of information, and the maxim of relationship or relevance. B complies with the politeness principles, rather than the cooperative principles, because he does not want to be under the impression of being impolite against the third person (Agatha).

\section{Code switching and code mixing Code switching}

In understanding code switching, scholars define it in different ways. For instance, Saville-Troike (2003) defines it as alternating two or more languages, the versions of one language, or even different language styles in a speech situation performed by a speaker or speech participant. In addition, according to Chaer and Agustina (1995) code switching is an indication of the transition of language use due to changing communication circumstances. Different from Saville-Troike, Chaer and Agustina defined code-switching as a generic term for referring to switches or transitions of two or more languages, some variations of one language, or even multiple styles from a variety of languages (Hymes (1972) and Rahardi (2001). Although they define code switching differently, they also agree that code switching refers to the transition of language use from one language variation to other language variations. This understanding of code switching can be illustrated in the following examples.

Ali and Ibrahim, who are both from pesantren 
(Islamic boarding school), arrive twenty minutes earlier before the class begins in the hall. Both are involved in a conversation on numerous topics using Arabic. While they are engrossed in the conversation, Anto, a college friend who is not from the pesantren and for sure cannot speak Arabic, shows up. Anto greets them in Indonesian. Then they immediately engage the conversation by using Indonesian. The transition from Arabic to Indonesian by Ali and Ibrahim takes place because of the change of a situation influenced by the presence of the third person. In this regard, the Arabic situation has changed into a situation of "Indonesiaanness", influenced by the presence of Anto as a new speech participant, initiating his speech using Indonesian.

Interlanguage code switching takes place when two people are having a conversation in English, which happens to be feasible because they are students of the Department of English Literature. In the middle of the conversation, suddenly another friend, who is now a student at the Department of Indonesian Literature and is not proficient in English, comes up. Next, the conversation shifts from English to Indonesian, so the third person can participate in the speech event.

The inter-dialect code switching happens when someone code-switches from informal Madurese language to èngghi-bhunten Madurese level, known as bhâsa alos, which is formal and polite one. This happens because a highly respected person is present among speech participants.

The inter-dialect code switching happens when one is asking for something from someone else, which of course performed with a soft tone of voice. However, when someone is angry, he of course will switch the code to a rough and loud voice tone.

\section{Code Mixing}

Code mixing is the use of a language unit from one language to another in order to extend the style of the language spoken or the language variety. It occurs when multilingual speakers use one or more similar languages (Kridalaksana, 2008). In this sense, code mixing occurs when a speaker predominantly uses a language and then supports his speech by inserting other language elements. Code mixing can occur in the absence of a necessity in a language situation, which calls for code mixing of language, inasmuch as it can also be feasible due to factors related to casualness, habits, or the absence of exact language equivalent to uncover a phenomenon. To have more understanding of code mixing, it can be described in the following example.

It is about someone who attempts to raise a sense of humor. Suppose there is a kiai who is speaking Indonesian in front of a majority of NUMME. He then code-mixes his speech by inserting Madurese words, which can crack laughter, in order to reveal a poorly fitting Arabic vocabulary if translated into Indonesian. Immediately, he code-mixes into Arabic language, and to show intimacy he code-mixes NUMME into bhâsa Malaju (BMlj) and Arabic. This usually relates to the speaker's characteristics, such as social background, educational level, and religious sense. These variables are all prominent features of a casual or informal situation. However, such mixing can happen also because of language limitations, making the expression in a language inappropriate to the communication context. As such, there is compulsion to use another language although it only supports one function.

According to Rahardi (2001), code mixing also includes language convergence (linguistic convergence). Code mixing is divided into two traits, including (1) mix the code into (inner codemixing), which deals with code mixing resulting from the original language with all of its variations and (2) outer code-mixing, pertinent to code mixing resulting from a foreign language. The background of code interference can be classified into two, inter alia (1) attitudinal type of speaker's background and (2) linguistic type concerning the background to language limitations. As a corollary, in a communication there emerges a reason for role identification, identification of variance, and desire to explain or interpret. Thus, code mixing occurs because of a reciprocal relationship among a speaker's role, language form, and language function. Some forms of code mixing include (a) the insertion of words, (b) inserting phrases (c) inserting clauses, (d) inserting idiomatic expressions, and (e) inserting coinage (combination of original and foreign forms).

The use of speech level in Madurese language (ML)

Commonly, in every language there are certain ways to identify the differences of attitudes between a speaker and their interlocutor involved in a speech event. For example, when the speaker is speaking to someone who does not need to be respected, they will, without a question, use speech code showing no respect (Rahardi, 2001).

The phenomenon occurs because in a speech community there are certain group members who are necessary to be respected in speaking, but in certain social groups it is not necessary to give a special honour. Therefore, actually speech levels can be broadly categorized into two traits, namely respectful form and casual form. The factors driving the use of these speech levels are somehow varied and different from one society to another. Public may be either respected or disrespected because of their physicality, economic power, social status, power, political influence, intimacy, age, sex, and physiological condition. 
Referring to the above elaboration, Madurese language speech level and its use in social interaction among Madurese societies can be portrayed as in Table 1.

Tabel 1. Madurese Language Speech Level

\begin{tabular}{|c|c|c|c|c|c|}
\hline \multirow{2}{*}{$\begin{array}{c}\text { Speech } \\
\text { level/variety }\end{array}$} & \multirow{2}{*}{ Participant's Relationship } & \multirow{2}{*}{ Usage } & \multicolumn{3}{|c|}{ Examples of Word Usage } \\
\hline & & & I & You & Yes \\
\hline $\begin{array}{l}\text { enjâ'-iyâa } \\
\text { (E-I) }\end{array}$ & $\begin{array}{l}\text { Participants of the same age } \\
\text { or slightly older; very } \\
\text { intimate }\end{array}$ & $\begin{array}{l}\text { Used among intimate } \\
\text { friends; by parents to their } \\
\text { children }\end{array}$ & sèngko' & bâ'na & iyâa \\
\hline $\begin{array}{c}\text { engghi-enten } \\
\text { (E-E) }\end{array}$ & $\begin{array}{l}\text { Younger speakers with } \\
\text { slightly distal social status }\end{array}$ & $\begin{array}{l}\text { Used among adults newly } \\
\text { acquainted or to parents }\end{array}$ & kaulâ & sampèyan & engghi \\
\hline $\begin{array}{l}\text { èngghi-bhunten } \\
\text { (Ë-B) }\end{array}$ & $\begin{array}{l}\text { Speakers of younger age } \\
\text { with fairly distal social } \\
\text { status; frequently } \\
\text { interacting }\end{array}$ & $\begin{array}{l}\text { Used when speaking to } \\
\text { manager or parents in law }\end{array}$ & bhâdhân kaulć & $\begin{array}{l}\text { panjhən- } \\
\text { nengngan }\end{array}$ & èngghi \\
\hline $\begin{array}{l}\text { bhâsa alos } \\
\quad \text { (BAl) }\end{array}$ & $\begin{array}{l}\text { Speakers with very distal } \\
\text { social status; hardly } \\
\text { interacting }\end{array}$ & $\begin{array}{l}\text { Used when speaking to Kiai } \\
\text { or exalted official }\end{array}$ & $\begin{array}{l}\text { dâlom/ } \\
\text { abdhina }\end{array}$ & $\begin{array}{l}\text { Ajunan, } \\
\text { padhâna }\end{array}$ & dhâlam \\
\hline $\begin{array}{l}\text { engghè-enten } \\
\text { (Eg-E) }\end{array}$ & $\begin{array}{l}\text { Older speakers; frequently } \\
\text { interacting }\end{array}$ & $\begin{array}{l}\text { Used by parents in law } \\
\text { when speaking to their } \\
\text { children in law or younger } \\
\text { neighbors }\end{array}$ & bulâ & Dhika & engghe \\
\hline $\begin{array}{l}\text { bhâsa Malaju } \\
\text { (ragam kota) } \\
\text { (BMlj) }\end{array}$ & $\begin{array}{l}\text { Slightly intimate speakers, } \\
\text { no familial relationship }\end{array}$ & $\begin{array}{l}\text { Used among school mates, } \\
\text { office mates, or other } \\
\text { ethnics }\end{array}$ & saya & Situ & iya \\
\hline
\end{tabular}

The classification was adopted from Sofyan (2016, pp/ 15-17) and parts of it were developed by the researcher based on the research topic

\section{Giving an honor to a teacher in NU culture}

Kiai of Islamic College (pesantren) has a social status and a great influence around the NU community because he is considered to be a teacher who has significantly contributed to nurturing and managing education in an Islamic boarding school, an alternative education of a rural society (Sutarto, 2002). Therefore, if kiai studies at one of the Islamic boarding schools, his descendants will regard the kiai of that Islamic school as the teacher as well as his descendants. This tradition of giving an honor to a teacher in an NU culture still exists, although many alumni have succeeded in establishing larger similar institutions. Further, it is not only the descendants who consider to be learned, but also his students are encouraged to give an honor ( $\left.t a^{\prime} d z i m\right)$ to the kiai of Islamic college, where he studies.

The utterances and the verbal communications are translated on the basis of socio-cultural background within the speech community (Sukarno, 2015). In the NU society of the Madurese ethnicity, the cultural understanding is not only represented through verbal language, but also through nonverbal language (body language). This is reflected in the use of politeness among kiais that requires students to honor his teacher. The phenomenon is shown in the data (1) in the form of verbal and nonverbal language at a wedding party in Sempolan Jember as in the following:

Data1: The result of participatory observations on the marriage settlement in Sempolan Jember, in the afternoon at $13.00 \mathrm{pm}$
One day in the marriage settlement, a very young man was sitting among the elderly kiais. Suddenly, there was one student who would do nyabis (a salutation given to parents or older people by clasping hands together, aligning the thumb with nose) (sungkem: Javanese) to one of the elder kiais who also sat there. The elder kiai then pointed using his thumb to the young man, while saying to his student, "nyabis ka kiai dimin" 'kiss the kiai's hands first'.

The elder kiai's nonverbal language through pointing using his thumb to the young man followed by the verbal language "nyabis ka kiai dimin" 'kiss the kiai's hand first' before shaking another kiai's hand in the data (1) defined as the code (symbol) to please one of his students to shake while kissing the kiai's hand, who is still relatively young, by which in that agenda, he also sat among the elderly kiais in the Sempolan village. Based on information coming from one kiai of that village, in fact, that relatively young man is lora (grandson of kiai), that in the past the elderly kiais had studied at his grandfather's Islamic boarding school.

\section{METHOD}

A qualitative method with ethnography of communication approach was used to achieve this research's objectives. Thus, it can give a comprehensive illustration and explanation about the patterns of communication among kiai NU in Madurese ethnics in a unique socio-cultural context 
and somehow describe how the socio-cultural aspect affects the patterns of communication among kiai NU in the Madurese ethnicity with a teacher-student background.

As coming to the research location, the researcher acts as an intelligent (disguising identity as researcher). This aims to keep the originality and validity of data. Data were collected during 20142015 period through participatory and nonparticipatory observations, interview, note-taking, and recording. Performing data recording aims to record the communication process between KT-KS both either in formal or informal situation and interviews with related objects to overcome the researchers' limitations in direct recording of the communication process both in participatory observation and interview. The recorded data were then transcribed into written form. The verbal (oral) and nonverbal (body language) data taken from the conversation / communication of two people or more and also informants in the field that had been collected and analyzed descriptively using components of SPEAKING-grid analysis. (Hymes, 1964; Schiffrin, 1994; Saville-Troike, 2003)

\section{RESULT AND DISCUSSION}

The patterns of communication among a kiai as a teacher and kiai as a student of this research are divided into two types of situations, i.e. formal and informal situations. This refers to Poedjosoedarmo (1979) who states that the use of speech levels as a politeness strategy is influenced by the level of relationship formality, social status between the speaker and the hearer. The formality of such a relationship can be created through the teacherstudent relationship and the speech situation. Hence, it can be described the KT-KS patterns of communication that have been formal relations in different situations.

\section{KT-KS patterns of communication in a formal situation}

In some meeting agendas of the board of $\mathrm{NU}$ members that involve kiai recognized as the teacher (KT) and kiai as the student (KS), the patterns of communication followed by the use of speech codes merely reflect the student's respect to the teacher, as shown in the data below:

Data 2: Kiai's Foreword

(KT):Assalaamu'alaikum warahmatullaahi wabarakaatuh (KS):Wa 'alaikum salaam warahmatullaahi wabarakaatuh

(KT):Alhamdulillaahi Rabbil 'aalamiin ashshalaatu wassalaamu alaa Rasuulillaah wa'alaa aalihi washahbihi ajma'iin. Saampona bhâdân kaulâ mundud kasimpulan dâri jawabhân sareng-sareng (santrè khusus sarêng alumni khusus), angèngèngè masalah kanca otabâ alumni khusus sè èlatè sareng orèng luar korang langkong saka'dinto "ènggi saè manabi coma' alatè otabâ adampingè coma kalabân bâdâ filtêr sè nyarèng sopajâ setèl sarêng kabâdâân sè ampon biasa kalabân salèng pengertèan.

'Alhamdulillahi Rabbil 'aalamiin ashshalaatu wassalaamu alaa Rasuulillaah wa'alaa aalihi washahbihi ajma'iin.

'After collecting all the answers from the students and the specific alumnus who has been trained by the experts, it is explained as follows. To me, it is still alright if only to train or accompany, as long as there is the filter to make sure that there is no contradiction with the Islamic school culture and understanding each other'.

The utterance (in data 2) begins with greeting and praising and in BA, it is referred as an identifier of identity and the custom of NU community who are mostly students' society. In the speech above, there is a statement 'èngghi saè manabi coma' alatè otabâ adampingè' 'it is still alright if only to train or accompany'. The phrase èngghi saè 'yes' it is alright' indicates that KT principally agrees to the external assistants to train and accompany the board and the teachers (asaatidz) during the training process, but on one condition that those external assistants must understand the Islamic school culture. This is further attested by the phrase 'coma' (but) which is a word of prerequisite, which suggests accepting the external assistants. Compare this with the following data:

Data 3:Samangkèn bâdân kaulâ anyo'ona pamangghi dâ' panjenengan sadhâjâ angèngèngè masalah bâtes-bâtes otabâ cara-cara kaangguy saterrosa. Maka dâri ka'dinto, parlo sami usaha kaangguy masami pamanggi (salèng pengertian). Pola bisa ajâgâ kasaèan hubungan kaangguy saterrosa, sanaossa bâdâ perubahanperubahan. Kalabân aparèng onèng ramburambu sarêng cara-cara, jughân berusaha pola sobung masalah dâ' budina.

\begin{abstract}
'At this meeting, I ask the idea from the attendees of meeting about the limitations or the methods that will be used next. Therefore, it needs an effort to unify the perception, which is likely able to maintain the next good relationships, although there will be changes later. By informing the boundaries (in pesantren) and the methods may minimize the problems that will occur '.
\end{abstract}

The utterance in data (3) is a continuation of data of the utterances (2) but in the form of a request, as stated in the quote above "anyo'ona pamanggi" 'I ask' and "sami usaha kaangguy masami pendapat." It needs an effort to unify the perception'. Those utterances are the form of request sentence in order that the participants of speech have the same opinion in managing the Islamic school. At the opening of speech, there is an utterance "angèngèngè masalah bates-bates otabâ cara-cara kaangguy saterrosa" 'about the 
limitations or the methods that will be used next'. The utterance can be differentially inferred by the participants because what it means by bates-bates ('limitations) in the utterance is not clear, and neither are the words cara-cara (ways). Pragmatically speaking, in this speech there is a violation of conventions that can determine the success of communication. According Grice (1975) and Nadar (2009) this violation is called a violation of the cooperative principles, especially the manner maxim. However, as a reflection of respect and modesty (tawadlu) in order not to be impolite (cangkolang) to KT, the kyais who were on the agenda did not ask about the intention of that utterance. It shows that this sort of communication puts more attention to the politeness principles. In the data (2) and (3) kiai of the Islamic school as a person who is respected in this formal speech uses the word panjenengan (you in more polite sense) categorized in È-B speech level (Java: Krama Inggil) which also shows adherence to the politeness principles.

KT in his closing speech uses the closing words and utterances that show a causal relationship (relevance) with the previous speech content. It can be seen in the following speech:

Data 4: Maka dâri ka'dinto, bâdân kaulâ anyo'ona pamanggi neng è papanggiân ka'dinto: (1) ponapa hal-hal sè kodhu èparèngagi onèng dâ' tenaga sè dâri luar, sopajâ ta' ngacèwa'agi dâ' tenaga sè dâri luar jughân ta' sala paham; (2) ponapa hal-hal sè kodhu èparèngagi onèng dâ tenaga dâlem, sopajâ orèng dâlem ta' arassa tertekan jughân ta' sala paham."

'Therefore, we ask for any suggestions in this meeting: (1) what should be presented to the external assistants in order they are not disappointed and also do not misunderstand? (2) What should be presented to the board and teachers, in order they are not depressed and do not misunderstand.

The utterance ' Maka dâri ka'dinto' (therefore) as the closing KT's preface has a causal relationship (relevance) to the previous speech content. In that utterance, there also contains BI loanwords such as maka 'therefore', tertekan 'depressed', and salah paham 'misunderstood'. This indicates that in formal situations KT frequently does code mixing into the commonly used BI vocabulary. The use of code mixing is intended to express vocabulary that is hard to find its equivalent in È-B speech level. It is also a form of strategy to ease the understanding of KS in inferring the KT speech.

That speech is, in fact, still continued with the word "Saterrosa" 'next' indicating that the utterance will be continued as it is stated in the following data:
Data 5: Saterrosa, kaangguy musyawarah sè bhâkal dâteng ènggi ka'dinto, angèngèngè masalah sistêm hubungan sasarengan. Sanyatana masalah ka'dinto èbantu tenaga-tenaga sè bisa è bhâdi panegghu'an/ penampungan masalah, jughân èssèna èngghi ka'dinto jhâlân kaluar kalabân ngalastarèaghi hal-hal sè pajhât parlo jughân ampon ma'lum. Coma' karena bâdâ pan-saponapan hal sè ghi' bellun bisa è lastarèaghi, maka ide akadiyâ marloagi bantuan tenaga dâri luar, ropana sè èmusyawaraaghi samangkèn ka'dinto.

(Next, what will be discussed in the upcoming meeting is about the system of relationship in the community of the Islamic school. Actually, this problem can be overcome by staff that can accommodate the problems in the Islamic school, and also it is a way to end the things that should have been known. However, as there are some things that have not been resolved, the solution of this problem is the help of external assistants that is now our topic at this meeting).

The reference of "masalah ka'dinto" (this problem) in the data (5) refers to "masalah sistem hubungan sasarengan" (the system of relationship in the community of Islamic college).' The implicature utterance of "Tenaga-tenaga sè bisa è bhâdi panêggu'ân" 'Staff members that can accommodate the problems in the Islamic school is that the ones who are able to be as the mediator in resolving the problems in the Islamic school'. That Implicature seems a little difficult to understand by the board of kiai of the Islamic school. Nevertheless, the attitude of the participants during the meeting never question or comment about the obscurity of the speech, thus the presupposition cannot be well concluded by the participants. The attitude of KS who are reluctant to question or comment about the main content of the speech delivered by KT reflects a part of the culture of the Islamic school that suggests a student to be modest (tawadlu) to his teachers. This phenomenon somewhat can lead to the wrong inferences towards the objectives of speech delivered by KT. Hence, it can be remarked that the difficult implicatures can cause the wrong inferences in response to the KT presupposition. To discuss the KT-KS patterns of communication in a formal situation, the following presentation reveal the analysis of components of speech.

The situation "place and milieu of speech" took place in a special room provided to the guests of the Islamic school who want to meet a kiai. The place and the situation of the speech is quite tenseIn that place not all students can stay at any time they want without being called by the kiai. Therefore, the place and the situation are very potential for having a formal and serious communication. This phenomenon is in line with the statement of Susanto (2014) and Sukarno (2015) that the relation between Javanese speakers is influenced by situations, speech purposes and 
professions. Such a phenomenon also prevails in Madurese ethnic society. Meanwhile, the participants in this event consisted of P1: Kiai as the teacher (KT) and P2: Kiai as the student (KS). The purpose (Ends) in the data 2, 3, 4, and 5 above is to give the understanding to unify the perception in improving the Islamic collage management. The type of speech (genres) is a kiai's serious welcome speech, but it is delivered in a flat tone as it is only a form of appeal and request to the head of the Islamic school who are the alumni of his school. Those utterances used a verbal language (instrumentalities) and did not use the sound system since the speech participants were not too many.

The act sequences in the meeting are as in the following: P1 pleased the board of kiai to come into the living rooms that are designed as the meeting room. P2 entered the meeting room. While waiting for the kiai who was still preparing for what would be delivered, the alumni waited quietly without making a conversation, except a small talk in a very low voice among other participants (fellow former students). P1 delivered the welcome speech by always directing his gaze to the participants of speech while P2 listened to the speech very carefully as he bowed his head. The norm of turn taking was first given to KT, only for one reason KT pleases KS (alumni) to state his opinion beforehand. Even the alumni would feel impolite (cangkolang) (Javanese: does not have a good attitude) to state his opinion, if he is not asked by KT.
The Interaction and interpretation norms in this event can be illustrated as follows: P2 as the speech participant always bowed his head as the realization of a sense of modesty (tawaduk) to the teachers. It is a part of the Islamic college culture on NU basis. Hence, sign language (body language) is often ignored, thus the purpose of speech cannot be well understood. In the tradition of NUMME, P2 rarely speaks without being asked by $\mathrm{P} 1$. If there is something crucial, P2 would ask for permission by saying "cabis pamator or cangkolang pamator." In general, in a formal situation KT always uses È-B language variation. Limitations on vocabulary that can be used in the È-B speech level, in a formal situation a kiai often does code mixing into BI. The BA is used as a specific identifier that almost all NU kiais are graduates of Islamic schools, thus they are considered to be fluent and accustomed to speaking Arabic. In formal situations such in data 3, 4, and 5 above, one way communication (one way traffic communication) occurs frequently because as a student, he will listen more to the conversation, as NU Jember terms this as adherence to dâbuna ghuru 'what the teacher says'.

Based on the data analysis, the results of the components of speech above, the interpretation that can be drawn is that generally in a formal situation, the KT-KS patterns of communication are as follows:

Table1 2: KT-KS Patterns of communication in a formal situation

\begin{tabular}{lcllll}
\hline \multirow{2}{*}{$\begin{array}{c}\text { Speech } \\
\text { Participants }\end{array}$} & $\begin{array}{c}\text { Speech } \\
\text { Level }\end{array}$ & $\begin{array}{l}\text { Language } \\
\text { Choice }\end{array}$ & $\begin{array}{c}\text { Tone } \\
\text { (Tone of } \\
\text { Voice) }\end{array}$ & Body Language & Turn Taking \\
\cline { 2 - 4 } KT & È- B & $\begin{array}{l}\text { BM } \\
\text { BI and } \\
\text { BA }\end{array}$ & $\begin{array}{l}\text { Higher than KS } \\
\text { tone of voice }\end{array}$ & $\begin{array}{l}\text { Starring at the speech } \\
\text { participants }\end{array}$ & $\begin{array}{l}\text { Dominant in the first } \\
\text { turn }\end{array}$ \\
KS & BM & Lower than KT & Bowing the head and \\
tone of voice & Looking under & $\begin{array}{l}\text { After KT or asking for } \\
\text { permission to talk }\end{array}$ \\
\hline
\end{tabular}

\section{The KT-KS patterns of communication in an informal situation}

In an informal situation KT and KS still strongly hold the politeness principles mentioned in Grice (1975) in communication. It can be seen from the use of speech codes that tend to show respect from a student to the teacher (see the Data 6 below).

Based on the code characteristics and proportions used by KT to communicate with KS who is relatively younger, in general, KT uses BM in E-E level mixed with È-B level code. Meanwhile, KS always uses BM in È-B level and BA1. Similarly, the tone (tone) used by KS is always lower than KT (see the signs $\downarrow$ for low tone and $\uparrow$ for high tone in the Data 6 below). The phenomenon can be seen in the following data:
Data 6: The communication of RAbd (KT) and Jml (KS)

(A) P1 : Dâgghi' panjenengan $\rightarrow$ tèlpon maghrib bhâ' ta' sibu'a? $\uparrow$

'Later, I will call you after evening prayers, aren't you busy?

(B) P2 : Ka'dinto. $\downarrow$ 'Yes, I am kiai'

(C)P1 : Ba' ta' sibu'a $\uparrow$ dagghi' maghrib? $\uparrow$ 'Don't you have any bustle after evening prayers'

(D)P2 : Ka'dinto $\downarrow$, lastarè maghrib abdina morok. $\downarrow$

'Yes, I am, after the evening prayers I will teach.'

(E) P1 : Lastarè isya' $\uparrow$ kol bâllu'? $\uparrow$

'After isya' prayers at eight o'clock?'

(F) P2 : Èngghi $\downarrow$, satengnga bâllu' bisa. $\downarrow$

'Yes, seven thirty I can.' 
(G)P1 : Sè lowong $\rightarrow$, pokol bâllu’ $\uparrow$ sampè pokol? $\uparrow$ 'From eight to what time you will have your spare time?'

(H)P2 : Satengnga bâllu' $\downarrow$ sampè ' pokol sanga'. $\downarrow$ 'Eight thirty to nine o'clock'

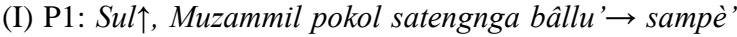
pokol sanga'. $\uparrow$

'Sul, Muzammil will be free at seven thirty until nine o'clock.'

(J) P3 : Ł̇ngghi

'Yes'

In the data conversation (6) there is a speech repetition with distinct patterning of communication, but the talk still has the same topic and purpose of speech, namely, 6(A) "Daggi" panjênêngan tèlpon maghrib bha' ta' sibu'a?" 'Later, I will call you after evening prayers, aren't you busy?'; 6 (C) 'Bha' ta' sibu'a dagghi' maghrib?" 'Don't you have any bustle after the evening prayers?' The repetition occurs because the answers P2 6 (B) "Ka'dinto" 'I am' and "Engghi" 'Yes' do not reflect the answers that indicate a sense of understanding to the questions delivered by P1. The misunderstanding is also based on the sentence pattern 6 (A) delivered by P1 is less clear. Therefore, P2 is afraid that he will give the wrong inference to the question P1. While the speaker's presupposition is hard to be accepted by the speech participant - in order not to violate the maxim of quality, sentence 6 (A) should be "Dagghi' manabi bâdhân kaulâ è bakto setelah maghrib telpen panjenengan bhâ ta' sibu'a?" 'Later, after the evening prayers if you have no bustle, what if I call?' To understand the utterance, P2 should understand the context of the previous discussion. In this case, the P2 as the hearer does not know the context of the previous discussion. This also means that the implicatures can be inferred correctly, if the hearer knows the context of the previous speech. In the conversation, $\mathrm{P} 2$ as a former student is not brave to refuse P1's request directly. However, by patterning such as in the data 6 (D) "Lastarè maghrib abdina morok" "After the evening prayers I will teach'. So the P2 answer is actually the polite statement of 'cannot'. Therefore, P1 immediately asked back 6 (E) "Lastarè isya' kol bâllu?" 'After isya' prayers at eight o'clock?' It also means that the $\mathrm{P} 2$ position as a former student is not brave to refuse directly, thus it requires the communication patterning that functions as a subtle rejection. The word ka'dinto in the data 6 (D), is a response from a former student to the teacher as a form of speech refinement of speech and respect for the interlocutor. Thus it can be also concluded that, social status and age factors can affect the patterns of communication. This is in line with the idea of Hymes (1972); Saviele \& troike (2003); Haryono (2011) stating that the age and social status are two very important things in shaping patterns of communication and strategies.
The situation 'place and milieu of speech' (context) took place in kiai's home, who is also an alumnus. They talked by phone. The speech participants consisted of P1: Kiai as the teacher (KT) P2: Kiai as the student (KS); P3: Student of $\mathrm{P} 1$. The purpose of speech in the data 6 dialogue is to ask the alumni's willingness to attend the meeting. The act sequences 'turn-taking' in the speech is as the following: P1 asked P3 to connect the phone to P2, P3 without saying anything, but directly looked for the phone book and then called P2; P1 started to talk, P2 answered every single question being asked by $\mathrm{P} 1 ; \mathrm{P} 1$ asked $\mathrm{P} 3$ to note the P2's available time to be called. The type of speech is in the form of spoken language delivered by phone with a serious tone. P1 used the higher tone of voice from other speech participants.

The Interaction and interpretation norms can be explained as follows: the KT-KS patterns of communication, seen from the code characteristics and proportion, used by $\mathrm{KT}$, in general, were often mixed with the BM code in E-E level and BM È-B level. Those formations can be seen from the vocabulary such as bâ 'apa' $6(\mathrm{C})$, which indicates the EE speech level. Words such as panjenengan, lastarè, are included in the BM vocabulary on the È$B$ speech level. Code-mixing with È-B speech level is used by $\mathrm{KT}$ as a form of respect to $\mathrm{KS}$ who is basically older. Meanwhile, P2 as KS always uses $\mathrm{BM}$ in E-B level and BAl. The use of politeness can be identified from the word " $k a$ 'dinto" 'I am' in the data 6 (B) which is categorized as È-B code. The use of the word "abdhina" 'I am' 6 (D) is a characteristic of the BAl code. The speech level and BAl were used as a form of ta'dzim (politeness) to $\mathrm{KT}$ which is in the NU tradition considered to reflect a higher social status than KS.

The KT age, which is older than KS, also determines the use of patterns of communication. It can be shown from the following data:

Data7: Conversation between KT-KS

(A) P1 : Assalaamu'alaikum

(B)P2:Wa'alikum salaam warahmatullaahi wabarakaatuh

(C) P1: ta' kaluaran? $\uparrow$

(D) P2: Bhunten. 'Don't you go anywhere?'

$$
\text { 'No' }
$$

(E) P1 : Dâgghi' malem musyawarah, ghè? $\uparrow$ 'Tonight, there is a conference, isn't it?'

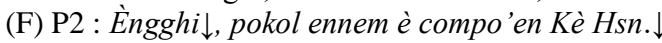
'Yes, at six o'clock in Kyai Hasan's home'

(G) P1 : Sèrah $\uparrow$ sè bisa? $\uparrow$ 'Who would come?'

(H)P2:Bellun $\downarrow$ èhubungi sadhâjâ ka'dinto. $\downarrow$ 'I haven't called all yet'

(I) P1 : Napè? $\uparrow$ 'What'

(J)P2: Anu.. ka'dinto $\downarrow$. Ngubungna $\downarrow$ P. Hari dimèn $\rightarrow$, P.Roji $\rightarrow$, pas terrossa ka Tompeng $\rightarrow$, pas bâli polè dâ' Kè Bakir $\downarrow$, ka'dinto. $\downarrow$ 
'there it is, I will call Mr. Hari first, then to Mr. Roji, continued to Tumpeng, and back again to Ki Bakir.'

(K)P1:Rofi'i nyambi kabbhi dagghi' kan $\rightarrow$, ghè? $\uparrow$

'All get on Rofi'i's vehicles, don't they?'

(L) P2 : Enggi. $\downarrow$

$$
\text { 'Yes' }
$$

(M) P1 : Bilâ Rofi’i èhubungè $\uparrow$, sopajâ nyampè aghi? 'Has Rofi'I been called to tell about this?'

(N) P2 : Ampon lastarè sadhâjâ $\downarrow$ dâ' $k a^{\prime}$ Rofi ' $i \rightarrow$, ka'dinto. $\downarrow$

'All have been completed toMr. Rofi'i.'

In the data (7) above, the purpose of speech is reflected in 7 (E) "Dagghi' malem musyawarah, ghè?" 'Tonight, there is a conference, isn't it?' The sentence is an interrogative sentence that functions as an affirmation whether P2 has prepared and invited the meeting participants that would be held tonight. This is also further confirmed in a next speech 7 (G) "Sèra sè bisa?" 'Who can come?'. As $\mathrm{KS}$ answered $7(\mathrm{H})$ "Bellun èhubungi sadhâjâ, ka'dinto" 'I haven't called all.' P1 then asked in a high tone 7 (I) "Nape?" 'What did you say?' The word Nape in this expression is very short but it has implied meaning more than what is stated: first, KT was surprised because KS had not yet called other meeting members. Second, as a reminder for P2 to immediately contact people who are already designated by P1. Therefore, P2 who felt nervous and feared directly responded with $7(\mathrm{H})$ " $a n u$, ka'dinto" 'O... there it is' and then followed by the name of the students who were going to be called. The word $a n u$, is as an attempt from P2 to clarify P1's insistence that he would soon do his orders. It also means that the patterns of communication with high tone can raise the feeling of fear from $\mathrm{P} 2$ as KS to P1 as KT. In this speech, P1 and P2 predominantly use the short sentences pattern, but they have a quite wide implied meaning, thus it can lead to the inference differently for the participants of speech.

This is an elaboration of components of speech analysis. The setting or situation 'place and milieu of speech' was placed in one of the alumni's home in the afternoon in an informal situation. The speech participants in the dialogue consisted of P1: Kiai the teacher (KT); P2: Kiai as the student (KS); P3: student of P2. The message form is a sort of serious conversation, although it is not formal, it feels tense for P1 while P2 started to worry. The speech purpose is to tell $\mathrm{P} 2$ to extend the information to other members, thus the alumnus of Islamic collage could attend the meeting held by kiai. The act sequence (turn taking) in this dialogue is as follows: P1 Greeted; P2 answered the greetings; P1 started the conversation; P2 answered every single question of P1 with the feelings of tense and fear causing nervousness in talking. The type of speech was serious and tense because kiai as the teacher started to wonder that most of the alumni have not been informed about the meeting's invitation that would be held by kiai, thus, the voice of P1 was higher than $\mathrm{P} 2$.

The interaction and interpretation norms describe that the conversation between $\mathrm{P} 1$ and $\mathrm{P} 2$ still holds the principles as teacher-students, even though in an informal situation. In general, the KTKS patterns of communication in an informal situation are as follows. The speech level used by $\mathrm{KT}$ is Eg-E (krama madya), while KS to KT used any variety of È-B and BAl (krama inggil and language of the palace). The topic may affect the speech situation, whether it is serious or relaxed. The purpose of speech is expressed in the form of implicatures that are accompanied by high tones as a realization of emotion which occurred during the conversation. The politeness principles (politeness) in the speech were well obeyed. In the speech, the age difference factor certainly determined the patterns of communication. By the age of $\mathrm{P} 1$ who is older than $\mathrm{P} 2$, there were no more codes from P1 showing vocabulary in È-B. Hence, the loud tone of voice conveyed by some interrogative sentences were predominantly used by P1 as well, while P2 just said yes, answered, and gave an explanation with a low tone of voice.

Based on the data analysis, the results of the components of speech above can be interpreted that generally, in informal situations the KT-KS patterns of communication is presented in Table 3 .

\section{CONCLUSION}

Giving an honor to the teacher in a paternalistic culture is a convention that is still maintained by the NU society. This phenomenon is reflected in the patterns of communication among kiais that have teacher-student ties (KT-KS). Although KS now is an alumnus who has become a kiai, he has to keep giving an honor to KT and the family as the teacher. The attitude of honoring is followed by the family, descendants, and even his students.

The communication patterns among the kiai bearing teacher-student ties (KT-KS) is influenced by both formal and informal situations. In a formal situation the KT-KS patterns of communication, when not using BI, he always uses formal language varieties, namely BAl and BM speech levels in È-B level. In an informal situation, the KT-KS patterns of communication are influenced by age differences. The age differences which affect the gap of KT-KS patterns of communication both in formal and informal situations are reflected only in the use of the speech levels, while on the language choice, tones of voice, the gaps were not found. 
Table 3. The KT-KS patterns of communication in informal situations

\begin{tabular}{|c|c|c|c|c|c|}
\hline \multirow[b]{2}{*}{ Participant } & \multicolumn{4}{|c|}{ Speech Codes Used } & \multirow[b]{2}{*}{ Turn Taking } \\
\hline & $\begin{array}{r}\text { Speech } \\
\text { Level }\end{array}$ & $\begin{array}{c}\text { Language } \\
\text { Choice }\end{array}$ & $\begin{array}{c}\text { Tone } \\
\text { (Tone of Voice) }\end{array}$ & $\begin{array}{c}\text { Body } \\
\text { Language }\end{array}$ & \\
\hline KT (younger age) & $\begin{array}{l}\text { E-E } \\
\text { E- B }\end{array}$ & $\mathrm{BM}$ & Higher than KS speech tone & Invisible, & Starting the speech, asking \\
\hline KS (older age) & $\begin{array}{l}\text { È- B } \\
\text { Bal }\end{array}$ & $\mathrm{BM}$ & Higher than KT speech tone & $\begin{array}{l}\text { due to via } \\
\text { phone }\end{array}$ & $\begin{array}{l}\text { The second turn answered } \\
\text { the question and giving the } \\
\text { reason }\end{array}$ \\
\hline KT (older age) & $\mathrm{Eg}-\mathrm{E}$ & $\begin{array}{l}\text { BM } \\
\text { BI and } \\
\text { BA }\end{array}$ & Higher than KS speech tone & $\begin{array}{l}\text { Staring to the } \\
\text { interlocutor }\end{array}$ & First turn \\
\hline KS (younger age) & $\begin{array}{l}\text { È- B } \\
\text { Bal }\end{array}$ & $\begin{array}{l}\text { BM } \\
\text { BI and } \\
\text { BA }\end{array}$ & Lower than KT speech tone & $\begin{array}{l}\text { Bowing his } \\
\text { head }\end{array}$ & $\begin{array}{l}\text { After the KT asked for } \\
\text { permission to talk }\end{array}$ \\
\hline
\end{tabular}

As a politeness form ( $t a^{\prime} d z i m$ - giving an honor and tawadlu') in both formal and informal situations, to the highly honored person (such as the KT KS), they always use polite language bhâsa alos (BAl) and the BM speech levels in the È-B level. They consistently used BM to attempt to lower the voice, bow their heads and or gaze, as well as adhere to turn-taking. It can be violated if the highly honored person gives the opportunity, or the person with a lower social status uses phrases such as cabis pamator/cangkolang pamator (asking permission to speak).

\section{REFERENCES}

Brown, G. \& Yule, G. (1983). Discourse analysis. Cambridge: Cambridge University Press.

Budhiono, R. H. (2010). Tuturan orang kaso: tinjauan etnografi komunikasi. Adabiyyāt: Jurnal Bahasa dan Sastra, 9(1), 155-172.

Chaer, A. \& Agustina L. (1995). Sosiolinguistik suatu pengantar. Jakarta: Rineka Cipta.

Grice, H.P. (1975). Logic and conversation. In Cole \& Morgen (Ed.). Radical Pragmatics. New York: Akademic Press, pp. 41-58.

Gumperz, J. (1968). The speech community. International encyclopedia of the social sciences, 381-386.

Halliday, M.A.K., Hasan, Q. (1992). Bahasa, Konteks, dan teks: Aspek-aspek bahasa dalam pandangan semiotik sosial [Language, Context, and Text: Aspect of Language in a Social-Semiotic Perspective.] Yogayakarta: Gadjah Mada University Press.

Haryono, A. (2011). Pola komunikasi warga NU etnis Madura sebagai refleksi budaya paternalistik. Humaniora: Jurnal Budaya, Sastra, dan Bahasa, 23 (2), 175-184.

Haryono, A. (2013). Pola komunikasi warga Nahdlatul Ulama etnik Madura di Jember (Unpublished Ph.D. Dissertation) Universitas Gadjah Mada, Yogyakarta, Indonesia.

Haryono, A. (2014). Penceritaan kisah ulama/kiai dalam tuturan sebagai pola dan strategi penyampaian pesan warga Nahdlatul Ulama etnik Madura. Humaniora: Jurnal Budaya, Sastra, dan Bahasa, 26 (3), 123-136.

Haryono, A. (2006). "Pola Komunikasi di Pesantren Salaf “A” di Jember" (Unpublished master thesis). Universitas Negeri Surabaya, Jawa Timur, Indonesia

Ibrahim, A.S. (1993). Kajian Tindak Tutur. Surabaya: Usaha Nasional

Hymes, D. (1964). Introduction: Toward ethnographies of communication. In J.J. Gumperz, \& D. Hymes, (Eds.), The ethnography of communication (pp. 1-34). Malden, MA: Blackwell

Hymes. D. (1972). Models of the Interaction of Language and Social Life. In J.J. Gumperz and D. Hymes (Eds), Directions in sociolinguistics: The ethnography of communication (pp. 35-71). New York : Holt, Rinehart, and Winston.

Kridalaksana, H. (2008). Kamus Linguistik ( $4^{\text {th }}$ ed.). Jakarta: Gramedia Pustaka Utama

Kuswarno, E. (2008). Etnografi komunikasi: Suatu pengantar dan contoh penelitiannya. Bandung: Widya Padjadjaran.

Leech, G. (2003). Sematik. Judul Asli: Semantic. Penterjemah: Partana, P. Yogyakarta: Pustaka Pelajar.

Leech, G. (1993). Prinsip-prinsip Pragmatik (The Princiiple of Pragmatic) Jakarta: UI Press.

Lubis, H.H.A. (1993). Analisis Wacana Pragmatik. Bandung: Angakasa.

Mulyana. (2005). Kajian Wacana, Teori, Metode, dan Aplikasi Prinsip-Prinsip Analisis Wacana. Yogyakarta: Tiara Wacana.

Muzadi, A. M. (2003). Apa dan Bagaimana Nahdlatul Ulama. Jember: Pengurus Cabang Nahdlatul Ulama Jember.

Nababan, P.W.J. (1987). Ilmu Pragmatik, Teori, dan Penerapannya. Jakarta: Dikbud

Nadar, F.X. (2009). Pragmatik \& Penelitian Pragmatik. Yogyakarta: Graha Ilmu

Poedjosoedarmo, S. (1979). Tingkat Tutur Bahasa Jawa. Jakarta: DEPDIKBUD.

Rahardi, K. (2001). Sosiolinguistik, Kode dan Alih Kode. Yogyakarta: Pustaka Pelajar Offset 
Sariono, A. (2007). Pemilihan bahasa dalam masyarakat Using: Studi kasus pada masyarakat using di Kelurahan Singotrunan, Kecamatan Banyuwangi, Kabupaten Banyuwangi. (Unpublished Ph.D. Dissertation) Universitas Gadjah Mada, Yogyakarta, Indonesia

Saville-Troike, M. (2003). Ethnography of communication: An introduction. New York: Blackwell Publishing Ltd.

Schiffrin, D. (1994). Approaches to discourse. Cambridge:

Searle, J. (1985). Speech Act. Cambridge: Cambridge University Press.

Setyowati, Y. (2013). Pola komunikasi keluarga dan perkembangan emosi anak (studi kasus penerapan pola komunikasi keluarga dan pengaruhnya terhadap perkembangan emosi anak pada keluarga Jawa). Jurnal Ilmu Komunikasi, 2(1), 67-78.

Sofyan, A. (2016). Bahasa Madura Dialek tSumenep. Yogyakarta: Galang Press.

Sukarno, (2015). Politeness strategies in responding to compliment in Javanese. Indonesian Journal of Applied Linguistics, 4(2), 226-236.

Susanto (2014). The pragmatic meaning of address terms sampean and anda. Indonesian Journals of Applied Linguistics, 4(1), 140-145.

Sutarto, A. (2002). Menjinakkan

Globalisasi. Jember: Kompyawisda dan Universitas Jember.

Wahyuningsih, S. (2014). Kearifan budaya lokal Madura sebagai media persuasif (analisis semiotika komunikasi Roland Barthes dalam iklan Samsung Galaxy versi Gading dan Giselle di pulau Madura). SOSIODIDAKTIKA: Social Science Education Journal, 1(2), 171-180.

Wibisono, B., \& Hariyono, A. (2009). Pola-pola Komunikasi Etnis Madura Pelaku Perkawinan Usia Dini (Kajian Etnografi Komunikasi). Retrieved from http://repository.unej.ac.id/handle/123456789/ 2638

Wibisono, B. (2005). "Perilaku Berbahasa Warga Kelompok Etnis Madura di Jember dalam Obrolan Dengan Mitra Tutur Sesama dan Lain Etnis ". Disertasi: Universitas Negeri Malang

Wijana, I.D.P. (2010). Pengantar Semantik Bahasa Indonesia. Yogyakarta: Program Studi S2 UGM bekerja sama dengan Pustaka Pelajar. Yule, G. (1996). Pragmatics. Hongkong: Oxford University Press. 